\title{
Prototype development of smart parking system powered by solar photovoltaic
}

\author{
M.Z.M. Nasir ${ }^{1}$, S. Salimin², B. Chan ${ }^{3}$, S.A. Jumaat ${ }^{4}$ \\ ${ }^{1,3}$ Faculty of Electrical and Electronic Engineering (FKEE), Universiti Tun Hussein Onn Malaysia, Malaysia \\ ${ }^{2,4}$ Green and Sustainable Energy Focus Group (GSEnergy), FKEE, Universiti Tun Hussein Onn Malaysia, Malaysia
}

\begin{tabular}{|c|c|}
\hline Article Info & ABSTRACT \\
\hline Article history: & This paper proposed the prototype of smart car parking powered \\
\hline Received Oct 28, 2019 & by photovoltaic. There is probability that cars will hit the wall or car out from \\
\hline Revised Dec 29, 2019 & power rating and sizing of PV panel suitable for smart car parking system \\
\hline Accepted Jan 3, 2020 & and design an ultrasonic parking sensor circuit to alert any obstacle while \\
\hline Keywords: & $\begin{array}{l}\text { car parking consists of distance sensors, LED, Arduino UNO potentiometer, } \\
\text { resistors, and Node MCU. Where, Arduino UNO as a microcontroller was }\end{array}$ \\
\hline Arduino UNO & coding to receive the signal from the sensor and transmit signal to LED \\
\hline Internet of things & $\begin{array}{l}\text { to display the car distance condition. To measure the distance between sensor } \\
\text { positions to a car, HC-SR04 ultrasonic distance sensor is used. Whenever a }\end{array}$ \\
\hline PV system & \\
\hline Smart car parking system & LED will light up and send the condition happening to the smartphone \\
\hline Ultrasonic sensor & $\begin{array}{l}\text { application. The application build-up can display the real situation and the } \\
\text { PV system can supply enough electricity to the smart car parking. }\end{array}$ \\
\hline
\end{tabular}

Copyright $\odot 2020$ Institute of Advanced Engineering and Science. All rights reserved.

\section{Corresponding Author:}

Suriana Salimin, Green and Sustainable Energy Focus Group (GSEnergy),

Universiti Tun Hussein Onn Malaysia (UTHM),

86400 Parit Raja, Batu Pahat, Johor, Malaysia.

Email: suriana@uthm.edu.my

\section{INTRODUCTION}

Nowadays, for comfort and safety driving, the current Driver Assistance System (DAS) was designed. The most used DAS is the smart parking system to detect surrounding car by using sensors [1]. The fast increment in the volume of vehicles in big cities has bring together the need for public parking spaces and increasing lighting to brighten the parking lot need renewable energy to cover the supply [2]. Photovoltaic is likely to evolve as the electrical energy source to the third generation of high-efficiency thin-film technology [3]. The ultrasonic sensor was needed to detect the distance between the car to barrier behind the car [4].

In [5] author write photovoltaic(PV) panels that use solar energy are used in lots of domestic and commercial houses, such as public parking garages, commercial centers, hypermarkets, and sub-urban apartments. In [6] author writes if photovoltaic technology is merged into design in building, it should consider the PV system technology. Identically, some other aspects, such as architectural aesthetics and ease of use of the building should be considered as well. In [7] proposes an efficient and robust maximum power point tracking based charge controller, a design and implementation of a low cost, suited for stand-alone or backup PV applications. At present, building integrated photovoltaic system can be divided into two classes; roof structure photovoltaic system and wall structure photovoltaic system [5].

In case of electrical damage or fault, the place became dark because of no electric supply. The driver was difficult to park cars because the loss of sign and the cars will hit the wall. Beside that drivers fail to 
detect the presence of obstacle behind the car. These conditions lead to driver easier to hit something behind the car. In [8] proposed the system that can avoid all the obstacles and cars on the road from time to time. Input data management unit was designed as a control unit for input data sensors of input and output control. Furthermore, the common alarm system is not efficient. Lastly, the driver unable to determine the distance between the car and an obstacle behind it. In [9] proposes a simple way of smart parking system. It monitors cars and incorrect parking by taking a signal from Ultrasonic sensors in a Moving Arduino. Then, the Moving Arduino analyse the signal to be converted to code, sending it by using a wireless radio frequency to the Fixed Arduino. In [10] use image processing methods to control the entrance of a smart parking by recognize car plate by step : preprocessing, License plate detection, character extraction and recognition.

Recently, the Internet of Things (IoT) became an emerging technology. One of the most significant current research discussion topics on the IoT is about the smart car parking. In [11] reveals a work-in progress to capitalize on private land properties for parking, in order to relieve stress on public agencies, create new sources of revenue, and enlist new entities in the intermediary market. The (IoT) paradigm expands the scope of cloud-based intelligent car parking services in smart cities, with novel applications that better regulate car-parking related traffic. In [12] designing the system and identifies the existing hardware and software automotive infrastructure that the robot first aid system car functionally use. A preliminary framework for the system's internet of things infrastructure is established to facilitate the development of a smart robot. In [13] design, analyze and implement "IoT based sensor enabled car parking system", this enables the user to pre reserve parking slot from remote place with the help of mobile application [14]. proposes a smart car parking system that will assist users to solve the issue of finding a parking space and to minimize the time spent in searching for the nearest available car park.

This paper proposed the prototype of smart car parking powered by photovoltaic. This study determines the power rating and sizing of PV panel suitable for smart car parking system and design an ultrasonic parking sensor circuit to alert any obstacle while parking and develop the prototype of smart car parking using PV.

\section{RESEARCH METHOD}

\subsection{Standalone Photovoltaic System}

Stand-alone PV system is designed to be operated independently, outside from the electric utility grid. It is designed and sized in order to supply a certain DC or AC electrical loads [15]. These types of system powered by a PV array only. A direct-couple system is the simple type of stand-alone system. The module DC output is connected directly to load which is also a DC. As there is no batteries in this system, the load can only be operated within hours of sunlight. Because of this reason, direct-couple system designs are suitable only for applications such as water pumps, ventilation fans, and small circulation pump for water heating system or solar thermal [14].

The simplest stand-alone system comprises of a module that supplies load directly, a battery charger controller, DC load and inverter for AC load. Figure 1 shows the stand-alone PV system configuration. When loads are being added, it is the task of the charge regulator to protect the battery from over-discharge. If one needs to power an AC appliances, inverter is needed so that the DC voltage can be converted to AC at $50 \mathrm{~Hz}, 230 \mathrm{~V}[16]$.

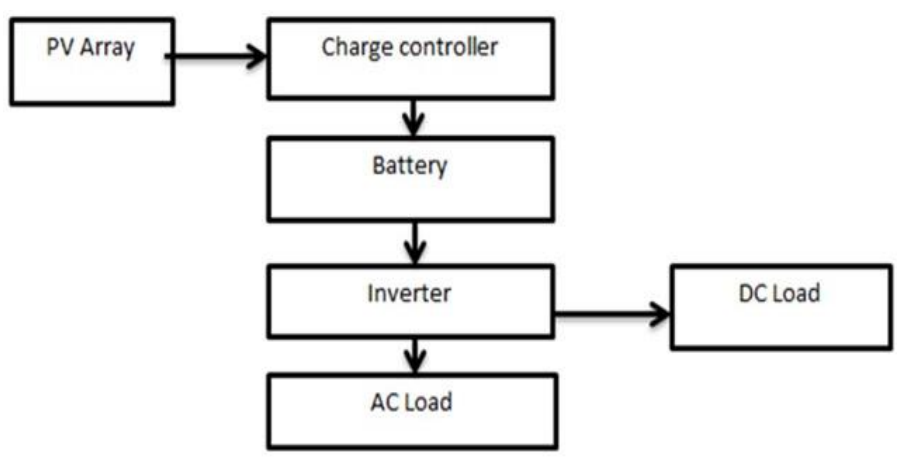

Figure 1. Standalone photovoltaic power system with battery 
Whenever over-charge happens, the rise in voltage will control the charging by series regulation or shunt regulation. Shunt regulator is used in small scale PV system as well as hybrid wind-PV system. It works by dissipating the additional energy generated to a dump load [17]. A simple shunt regulator circuit is shown in Figure 2. Batteries act as a central reservoir into which electricity is placed and removed. Batteries will store electricity so that it can deliver the power over an extended time period. Furthermore, batteries provide the ability to send large amounts of current for a short time periods. Battery is a device that changes the chemical energy into electrical energy by putting the certain chemicals for each contact in specific way [18].

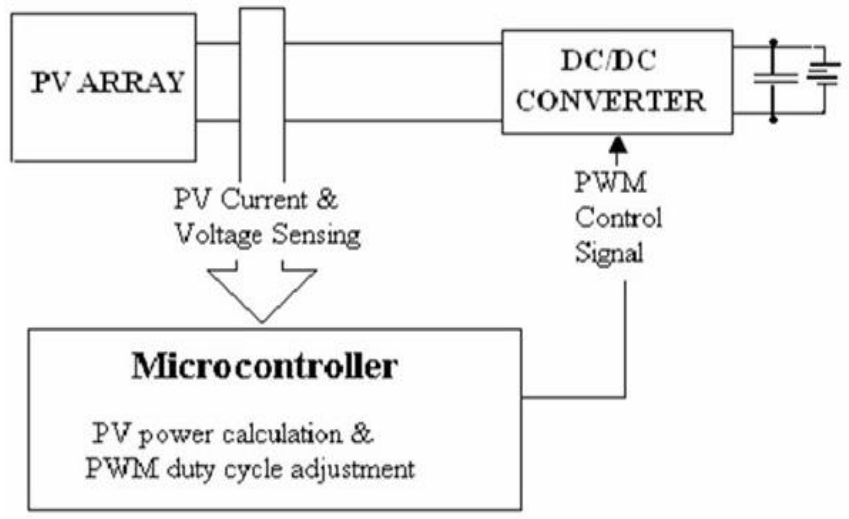

Figure 2. Shunt regulator circuit [17]

\subsection{Sizing of PV System Component}

In this project, there are formulas used to obtain the appropriate value. One of the formulas to be used is the formula for obtaining the value of voltages required by the solar panel. Next, the formula for obtaining the battery value to be used in this project. Besides, this project should use the formula to obtain value of energy use per day. Additionally, the number of solar modules required need to be calculated to get enough solar modules. The required power rate for a relatively small solar system is usually calculated in watts unit over kilowatts [19]. Determining the value of daily power requirement is the same as the value of the required power load and the period of use or operation of the load in a day. (1) is the formula for calculating daily power requirement.

$$
W \times h=W h
$$

Where $\mathrm{W}$ is the power for load, $\mathrm{h}$ is the time of use and $\mathrm{Wh}$ is daily load requirements. This project uses 6 Led light with 2 volts for each one with total operation current of 1.12 A. Assuming it operates for 120 seconds each day, the daily power requirement based on (1) is $0.04 \mathrm{Wh}$. The battery is chosen according to (2).

$$
\text { Battery size in } A H=\frac{\text { total } \frac{w h}{d a y}}{0.85 \times 0.5 \times V_{\text {batt }}} \times \text { day }
$$

As there is no battery as rated in the market, thus minimum battery chosen is 1.2 Ah. The PV cell required value is calculated as Watts / 4 hours of sunshine per day and that will be the panel size which is $0.16 \mathrm{~W}$. Again, for the same reason, $1 \mathrm{~W}$ solar panel size is used in the project [20].

\subsection{Designing the Smart Car Park}

The smart car park component consists of ultrasonic sensor, LED, buzzer, MSU node and Arduino UNO. This is shown as in Figure 3. Car parking sensor, HC-SR04 ultrasonic distance sensor is used to measure the distance from a sensor position to a car [21]. Node MCU act as microcontroller to controls the overall parking system by communicating with the server [22]. Car moves along the path and identifies the obstacles around it through the ultrasonic sensor. The driver able to know the blocks it belongs to and to classify the vehicles around it into three types at the same time [23]. Arduino UNO store the data and sent data to MCU node then the data direct to database [24]. Figure 4 illustrates the process in detail. 


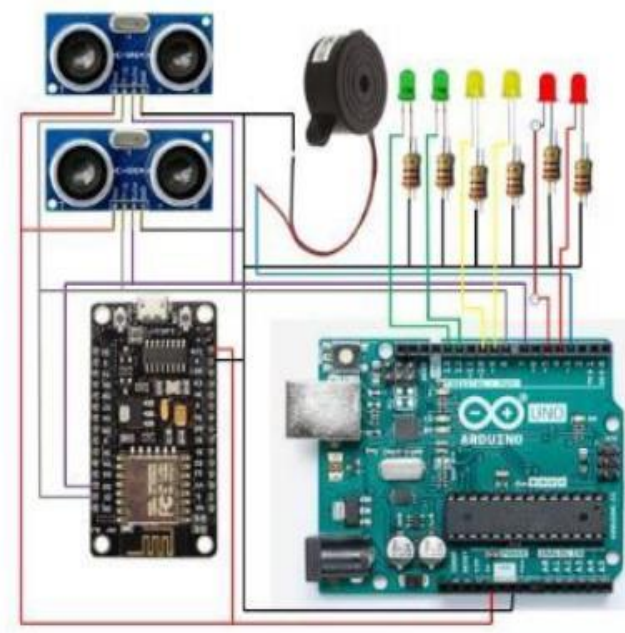

Figure 3. Ultrasonic parking sensor circuit

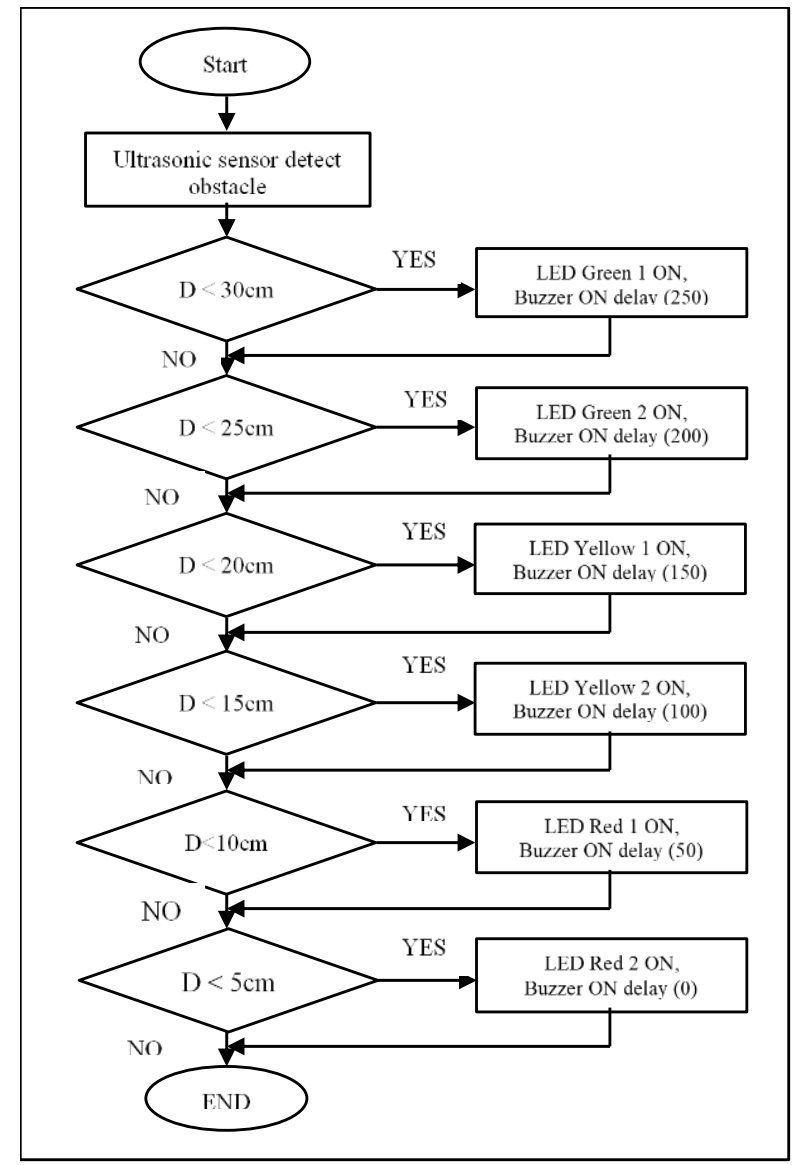

Figure 4. Process flowchart of ultrasonic sensor with $\mathrm{D}=$ Distance

Smart parking system has a processing unit that processes the data od distance between car and wall and shows the parking distance to the driver [25]. When the car approaches sensor and gets in range will light up red, yellow or green LED depending on distance readings. The algorithm is very simple; read the value of the variable resistor and translate it into centimeters, check deviation and read distance from the ultrasonic sensor, and check whether current distance in a range and turn on corresponding led when needed. Following that, it will repeat the procedure.

\section{RESULTS AND ANALYSIS}

Figure 5(a) show voltage battery value is almost $12 \mathrm{v}$ by using multimeter. Shows that system solar panel is working. It is because the battery get voltage from solar panel and the battery always charging. While in Figure 5(b) show voltage value of output from charge controller using multimeter. The voltage of output was $12 \mathrm{v}$ because the solar panel and battery supply $12 \mathrm{v}$ to output. When the output get $12 \mathrm{v}$ it means the solar panel system it function from panel solar to battery and supply to output by using charge controller.

This project is programmed based on conditions as summarised in Table 1 . If the distance between the car and the wall is in the range of $25 \mathrm{~cm}$ and $30 \mathrm{~cm}$, the green $1 \mathrm{LED}$ will ON. This shows safe condition of the car. If the distance between the car and the wall is in the range of $20 \mathrm{~cm}$ and $25 \mathrm{~cm}$, the green 2 LED will ON. This still shows safe condition of the car. But if the distance between the car and the wall is in the range of $15 \mathrm{~cm}$ and $20 \mathrm{~cm}$, the yellow 1 LED will ON. This means the driver needs to beware when to stop the car. If the distance between the car and the wall is in the range of $10 \mathrm{~cm}$ and $15 \mathrm{~cm}$, the yellow 2 LED will $\mathrm{ON}$. The driver is now must be in alert condition. If the distance between the car and the wall is in the range of $5 \mathrm{~cm}$ and $10 \mathrm{~cm}$, the red 1 LED will ON. Again it is not in the safe condition and driver must be extra careful not to go further. The last condition in when the red 2 LED turn ON. This is met when the distance is less than $5 \mathrm{~cm}$. Figure 6 shows the screenshot of notification in the handphone application during the process. 


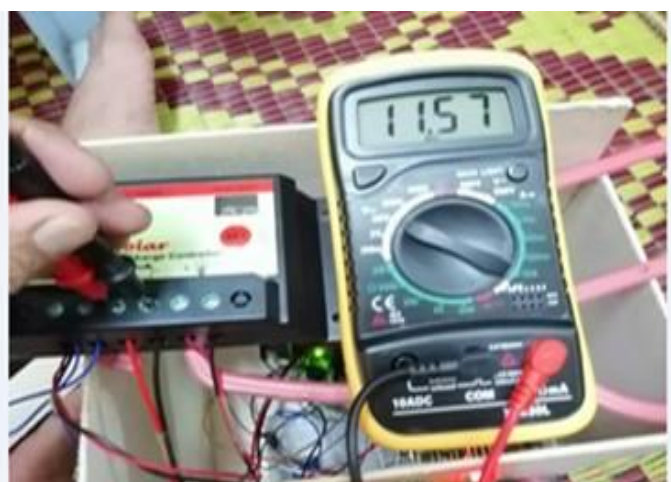

(a) Measurement of battery voltage

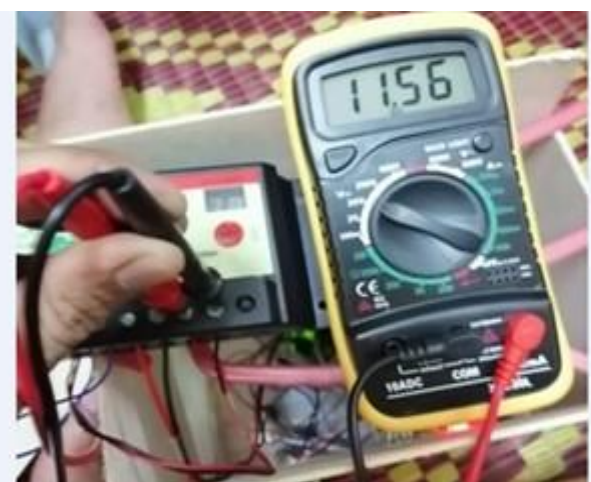

(b) Measurement of PV output voltage

Figure 5. Output voltage from (a) battery and (b) PV charge controller

Table 1. Condition of LED based on Distance

\begin{tabular}{cccc}
\hline LED & From $(\mathrm{cm})$ & To $(\mathrm{cm})$ & Condition \\
\hline Green 1 & $\leq 30$ & $>25$ & Safe \\
Green 2 & $<25$ & $>20$ & Still safe \\
Yellow 1 & $<20$ & $>15$ & Beware \\
Yellow 2 & $<15$ & $>10$ & Alert \\
Red 1 & $<10$ & $>5$ & Be careful \\
Red 2 & $<5$ & 0 & Danger \\
\hline
\end{tabular}

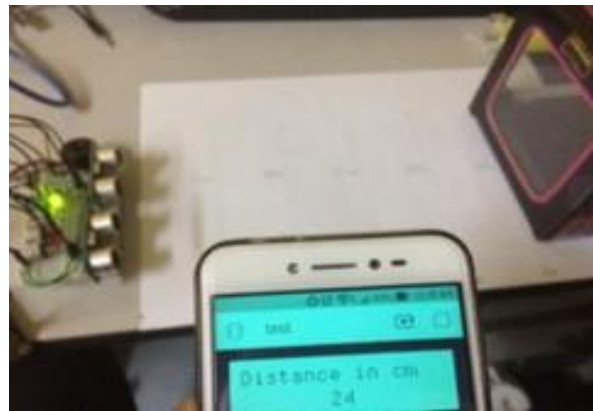

(a) distance $24 \mathrm{~cm}, \mathrm{LED}$ green 2 on

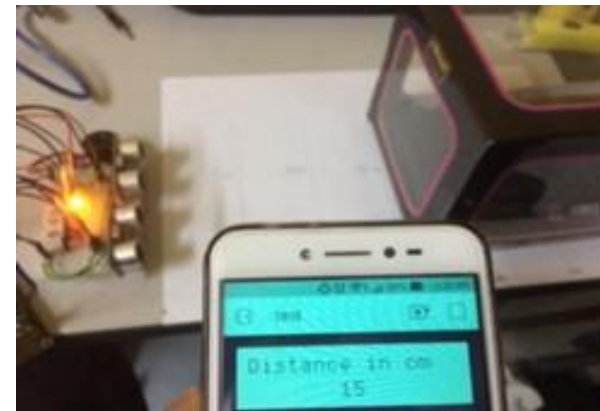

(b) distance $15 \mathrm{~cm}$, LED yellow 2 on

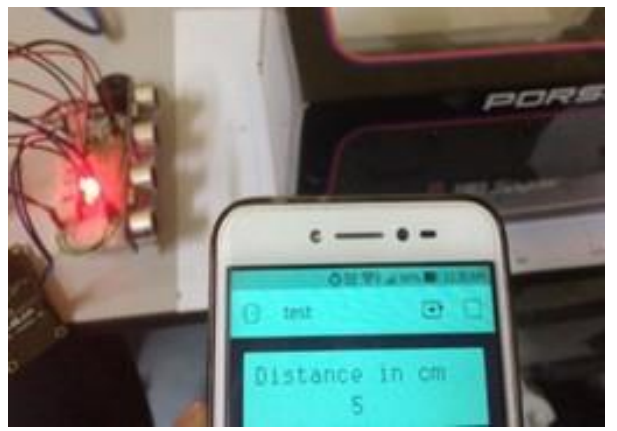

(c) distance $5 \mathrm{~cm}$, LED red 2 on

Figure 6. Notification received in handphone when condition is met (from safe to danger condition)

\section{CONCLUSION}

This paper has successfully shown a prototype development of smart parking system powered by solar PV as its source. The implementation of ultrasonic is great for obstacle or object detector. When using LED as an indicator, it is clearly showing the use of it is very good for indicating something for the alert and the function of buzzer also shown there are suitable to be an alarm. It will simultaneously reduce the common problem like costing of product and power consumption. Node MCU also functions to connect online update 
about the distance assign by the obstacle applied. This project is practical in daily life to monitoring the distance the bumper of the car to the obstacle behind to avoid accident because the rear of the car is the area blind to the driver. Thus, must always alert about the current situation happen before crash coming.

\section{ACKNOWLEDGEMENTS}

The authors would like to acknowledge the Research Management Center (RMC), Universiti Tun Hussein Onn Malaysia (UTHM), Batu Pahat, Johor, Malaysia for the financial support of this paper publication under the H157 (Tier 1) Grant.

\section{REFERENCES}

[1] M. Chowdhury and K. Dey, "Intelligent transportation systems-a frontier for breaking boundaries of traditional academic engineering disciplines [Education]," IEEE Intell. Transp. Syst. Mag., vol. 8, no. 1, pp. 4-8, 2016.

[2] R. F. Rahmat, S. Purnamawati, J. Kurnianto, S. Faza, and M. F. Pasha, "Vacant parking space identification using probabilistic neural network," Indones. J. Electr. Eng. Comput. Sci., vol. 14, no. 2, pp. 887-894, 2019.

[3] A. Zerga, E. Christoffel, and A. Slaoui, "Two-Dimensional modelling of polycrystalline silicon thin film solar cells," Proc. 3rd World Conf. Photovolt. Energy Convers., vol. B, pp. 1053-1056, 2003.

[4] Y. Kang, D. Jung, and I. Doh, "Automated parking lot management system using embedded robot type smart car based on wireless sensors," 2017 27th Int. Telecommun. Networks Appl. Conf. ITNAC 2017, vol. 2017-Janua, pp. 1-6, 2017.

[5] E. W. Smiley and L. Stamenic, "Optimization of building integrated photovoltaic systems," Conf. Rec. IEEE Photovolt. Spec. Conf., pp. 1501-1503, 2002.

[6] R. González, H. R. Jiménez, J. M. Huacuz, and G. Munguia, "First 3-phase grid-connected photovoltaic system in Mexico," 2006 3rd Int. Conf. Electr. Electron. Eng., no. December, 2006.

[7] M. N. Qaiser, M. Usama, B. Ahmad, M. A. Tariq, and H. A. Khan, "Low cost, robust and efficient implementation of MPPT based buck-boost converter for off-grid PV applications," 2014 IEEE 40th Photovolt. Spec. Conf. PVSC 2014, pp. 3701-3706, 2014.

[8] K. J. Yong and M. H. Salih, "Design and implementation of embedded auto car parking system using FPGA for emergency conditions,” Indones. J. Electr. Eng. Comput. Sci., vol. 13, no. 3, pp. 876-883, 2019.

[9] F. Alshehri, A. H. M. Almawgani, A. Alqahtani, and A. Alqahtani, "Smart Parking System for Monitoring Cars and Wrong Parking," 2019 2nd Int. Conf. Comput. Appl. Inf. Secur., pp. 1-6, 2019.

[10] M. S. Farag, M. M. Mohie El Din, and H. A. El Shenbary, "Parking entrance control using license plate detection and recognition," Indones. J. Electr. Eng. Comput. Sci., vol. 15, no. 1, pp. 476-483, 2019.

[11] Y. Atif, J. Ding, and M. A. Jeusfeld, "Internet of Things Approach to Cloud-based Smart Car Parking," Procedia Comput. Sci., vol. 58, no. Euspn, pp. 193-198, 2016.

[12] J. G. Kurebwa and T. Mushiri, "Internet of things architecture for a smart passenger-car robotic first aid system," Procedia Manuf., vol. 00, no. 2016, pp. 27-34, 2019.

[13] B. M. Mahendra, S. Sonoli, N. Bhat, Raju, and T. Raghu, "IoT based sensor enabled smart car parking for advanced driver assistance system," RTEICT 2017-2nd IEEE Int. Conf. Recent Trends Electron. Inf. Commun. Technol. Proc., vol. 2018-Janua, pp. 2188-2193, 2018.

[14] W. Alsafery, B. Alturki, S. Reiff-Marganiec, and K. Jambi, "Smart Car Parking System Solution for the Internet of Things in Smart Cities," 1st Int. Conf. Comput. Appl. Inf. Secur. ICCAIS 2018, pp. 1-5, 2018.

[15] V. Karthikeyan, G. Vijaysaikumar, B. Sumanthreddy, G. Abhilash, S. B. A. S. Ali and B. Ramkiran, " Performance analysis of standalone photovoltaic system," 2017 Third International Conference on Advances in Electrical, Electronics, Information, Communication and Bio-Informatics (AEEICB), Chennai, 2017, pp. 486-490.

[16] W. Ali, H. Farooq, A. U. Rehman, Q. Awais, M. Jamil, and A. Noman, "Design considerations of stand-alone solar photovoltaic systems,” 2018 Int. Conf. Comput. Electron. Electr. Eng. ICE Cube 2018, pp. 1-6, 2019.

[17] N. Amin, L. Z. Yi and K. Sopian, "Microcontroller based smart charge controller for standalone solar photovoltaic power systems," 2009 34th IEEE Photovoltaic Specialists Conference (PVSC), Philadelphia, PA, 2009, pp. 1094-1097.

[18] N. Idris, A. M. Omar, and S. Shaari, "Stand-alone photovoltaic power system applications in Malaysia," PEOCO 2010-4th Int. Power Eng. Optim. Conf. Progr. Abstr., no. June, pp. 474-479, 2010.

[19] T. Ma and O. Mohammed, "Plug-in vehicles car park photovoltatic farm construction for cost and emission reductions,” 2013 IEEE Energy Convers. Congr. Expo. ECCE 2013, pp. 5179-5184, 2013.

[20] D. Moroni, G. Pieri, G. R. Leone, and M. Tampucci, "Smart cities monitoring through wireless smart cameras," 2019 IEEE Int. Conf. Commun. Work. (ICC Work., pp. 1-6, 2019.

[21] R. Grodi, D. B. Rawat, and F. Rios-Gutierrez, "Smart parking: Parking occupancy monitoring and visualization system for smart cities," Conf. Proc. - IEEE SOUTHEASTCON, vol. 2016-July, pp. 1-5, 2016.

[22] J. T. Ang, S. W. Chin, J. H. Chin, Z. X. Choo, and Y. M. Chang, "ISCAPS-Innovative smart car park system integrated with NFC technology and e-Valet function," 2013 World Congr. Comput. Inf. Technol. WCCIT 2013, pp. 1-6, 2013.

[23] D. Vakula and Y. K. Kolli, "Low Cost Smart Parking System for Smart Cities," Proc. Int. Conf. Intell. Sustain. Syst. ICISS 2017, no. December 2016, pp. 280-284, 2018. 
[24] D. Kanteti, D. V. S. Srikar, and T. K. Ramesh, "Intelligent smart parking algorithm," Proc. 2017 Int. Conf. Smart Technol. Smart Nation, SmartTechCon 2017, pp. 1018-1022, 2018.

[25] S. Kazi, S. Nuzhat, A. Nashrah, and Q. Rameeza, "Smart Parking System to Reduce Traffic Congestion," 2018 Int. Conf. Smart City Emerg. Technol. ICSCET 2018, pp. 1-4, 2018.

\section{BIOGRAPHIES OF AUTHORS}
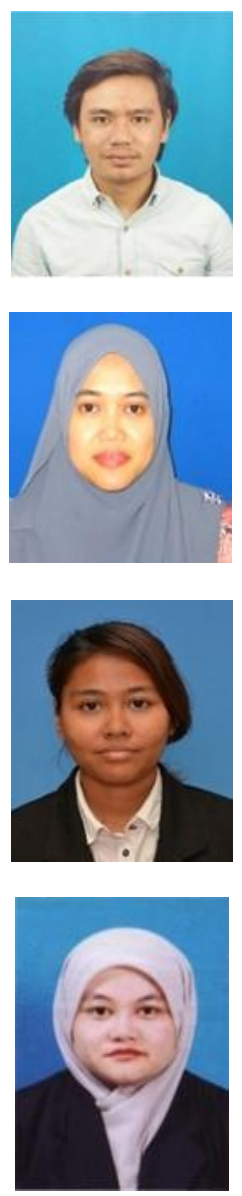

Muhammad Zahid Muhammad Nasir is a student of Faculty Electrical and Electronic Engineering in UTHM, Malaysia. His major study is Power Electrical Engineering. Among the courses undertook is Electronic Communication System, Industrial Power System, Electrical Design Project and Generation Transmission and Distribution System.

Suriana Salimin is a lecturer in Faculty of Electrical Engineering (FKEE), UTHM. After graduated from her first degree in Eletrical Engineering (UTM-2006), she worked as a tutor in UTHM for 6 months and continued for MSc in Power Distribution Engineering in Newcastle University (2007). She completed her $\mathrm{PhD}$ in Electrical Engineering in 2014 also from Newcastle University, UK. She has published a few papers in Jurnals and proceeding since 2013. Her research interests are on power quality improvement, distributed generation systems, renewable energy and harmonics mitigation

Baythanee A/P Chan received her B.Eng Electrical Engineering degree from Faculty of Electronics and Electrical Engineering (FKEE) University Tun Hussein Onn Malaysia (UTHM), Johor Malaysia. She future studies master's in electrical engineering at same university in research mode.

Siti Amely Jumaat was born in Johor, Malaysia on March 12, 1979. She graduated from the Institut Tun Hussein Onn (ITTHO-UTM) with honours degree in BSc. Electrical Eng. in 2001, MEng. (Power), UTM in 2003, and PhD in Electrical Eng at UiTM, Malaysia in 2015. Her research interests include power system and optimization techniques, FACTS devices, Artificial Intelligent techniques and renewable energy system. She is also a member of BEM, IEM, IEEE, and IEEE Power Engineering Society (PES). 